\title{
Editorial
}

\section{Laboratory Identification of SARS-CoV-2 for Confirmation of COVID-19 Cases}

\author{
MA Alam
}

COVID-19 (corona virus disease 2019) is currently a nightmare to the whole world. The pandemic included more than 10 million confirmed cases with the death toll of more than 0.5 million on the $30^{\text {th }}$ June, $2020^{1,2}$. The cases of infections and the deaths caused by COVID-19 are increasing every day.

We can remember the last days of December, 2019, when few clusters of serious pneumonia cases of unknown aetiology were identified in Wuhan City of Hubei province, China and on $31^{\text {st }}$ December, 2019. The Chinese authority reported these clusters to World Health Organization (WHO) $)^{3,4}$. The causative agent was isolated on $7^{\text {th }}$ January, 2020 and identified by the Chinese Centre for Disease Control and Prevention (Chinese CDC) as a noble corona virus and named it 2019-n-CoV ${ }^{4}$. On 30 ${ }^{\text {th }}$ January, WHO declared the 2019-nCoV outbreak as public health emergency of international concern (PHEIC) to aim at prevent or reduce the international spread of the disease and minimize interference with international traffic $c^{5,6}$. On $11^{\text {th }}$ February, 2020, WHO named the disease as COVID $-19^{5}$ and on the same day, the virus was renamed by the International Committee for Taxonomy of viruses (ICTV) as SARS-CoV-27. Soon the infections spread to other provinces of China and then to neighboring countries first and subsequently to other countries of the globe appearing as a large pandemic ${ }^{8,9}$. Scientists all over the globe were trying to understand the source of the outbreaks, infectiousness of the virus, and modes of transmission and to design the preventive measures ${ }^{10-13}$. Laboratory identification of unique sequences of the virus RNA by real-time reverse transcriptase-polymerase chain reaction (RT-PCR) from specimens of suspected COVID-19 patients is required for confirmation of the disease ${ }^{14-17}$.

For PCR diagnosis, specimens from upper respiratory tract including nasopharyngeal \& oropharyngeal secretions should be collected in plastic handled, noncotton swabs (Dacron or polyester-flocked swabs); wooden handle and cotton may contaminate clinical specimens to interfere with identification of the nucleic acids $^{14}$. Although it is worthy to mention that a few studies showed almost similar sensitivities with consumer grade cotton swabs for detection of SARS$\mathrm{CoV}-2^{18,19}$. Lower respiratory tract specimens include sputum, endotracheal aspirate and bronchoalveolar lavage in patients with more severe respiratory disease $^{14,20}$. The viral loads in throat swab and sputum

Dr. Md. Ashraful Alam, MBBS, M Phil (Microbiology), PhD, Professor \& Head, Department of Microbiology, Faridpur Medical College, Faridpur.

\section{Address of correspondence :}

Dr. Md. Ashraful Alam, MBBS, M Phil (Microbiology), PhD, Professor \& Head, Department of Microbiology, Faridpur Medical College, Faridpur. Phone: +88-01711380232,

E-mail: ashrafalam.bd@gmail.com specimens were found to be peaked at around 5-6 days after symptoms onset, ranging from around $10^{4}$ to $10^{7}$ copies per $\mathrm{ml}^{20}$. Although respiratory specimens showed greatest yields, additional clinical specimens may be collected as SARS-CoV-2 has been detected in blood and stool ${ }^{14,20-22}$. The WHO recommends stool, whole blood and urine for autopsy purposes ${ }^{14}$. Specimens storage until testing in in-country laboratories may also play important role. The WHO recommends, naso- and oropharyngeal specimens to be collected with Dacron or polyester-flocked swabs into viral transport medium (VTM) and stored at $2-8^{\circ} \mathrm{C}$ for up to 5 days storage ${ }^{14}$. The document also recommends that sterile normal saline can be used in place of VTM, but duration of specimen storage at $2-8^{\circ} \mathrm{C}$ could be different. Storage of the specimens for more than 5 days should be at $-79^{\circ} \mathrm{C}$ or dry ice.

Specimen collection procedure may minimize sensitivity, because SARS-CoV-2 viruses primarily colonize on pharyngeal mucosa and if collection procedure cannot adequately collect mucus secretions from these colonizing sites, collected specimen may not contain enough viruses to identify by RT-PCR. In addition, laboratory procedure to use only a little amount $(10 \mu \mathrm{l})$ of specimen with release reagent may also reduce sensitivity if the highest representation of the clinical specimen is not ensured during laboratory procedure of RNA extraction/release.

All clinical specimens from suspected COVID-19 patients should be regarded as potentially infectious. It is recommended to handle clinical specimens only by the properly trained and competent personnel in the laboratories meeting additional containment requirements and practicing in biosafety level (BSL-3). Initial processing of these specimens before inactivation of the viruses by external lysis buffer must be performed in an appropriately maintained and validated biological safety cabinet (BSC) $)^{14,23}$.

On testing specimens, results could be of 3 different types: (i) positive if one or more of the genes on SARSCoV-2 RNA genome along with or without internal control (IC) has been yielded on PCR analysis, or (ii) negative when finding no recognized gene, but rightly showing IC or (iii) invalid/indeterminate when PCR product could not show any of the genes as well as the IC. Invalid results could be due to too low specimen concentration or presence of any interfering substances that inhibited the reaction.

False positive and false negative results can be caused by poor specimen quality, improper specimen collection, improper transportation, improper laboratory processing or a limitation of the testing 
technology. Mutation in the target sequence of the SARS-CoV-2 or change in the sequence due to virus evolution may lead to false negative results. Improper reagent storage may lead to false negative results. Test assay is also limited to the personnel trained in the procedure and failure to follow strictly the test protocol may yield in erroneous results ${ }^{24}$.

False positive results with remnants of viral RNA fragments in the upper respiratory tract during convalescence period could be an embarrassing for the clinicians as well as for the laboratorians. Because, in such cases, there could not be any symptom suggesting of suspected COVID-19 or more exactly patient could be recovering from the illness. As mentioned earlier, false positive results could be due to many other reasons including contamination by the positive specimens by faulty packaging and transport, contamination in the laboratory due to crosscontamination during careless handling of specimens. It has been also reported that laboratory air pollution (contamination) with extracted viral RNA was found to occur when air dropping over working PCR plates could yield false positive results to most of the specimens. Similarly, false negative results could be yielded from faulty collection of specimens being unable to pick up specimen rightly or collecting specimen too early (RT PCR test added little diagnostic value in the days immediately after exposure), ${ }^{25}$ to reduced sensitivity of the pre-PCR reagent (master mix).

Therefore, if clinical suspicion is high, SARS-CoV-2 infection should not be ruled out on the basis of the results of RT-PCR alone, clinical and epidemiological situation should be carefully considered. Moreover, test results may vary among laboratories using different protocols, equipment and different reagents as well as with same protocols, equipment and reagents, but having some biased compounding factors like specimen storage duration, specimen storage suspending fluids, etc.

Sometimes, some sorts of confusion arises with very much unpredicted results from the laboratory. Some unpublished reports are known with some patients showing positive results for few months together; people often become confused whether test procedures are faulty. But in reality, this can happen to an individual because studies showing frequently change to their genomes and it is assumed that an infecting SARS-CoV-2 virus mutates in an immunocompetent individual several times- for which the previously developed neutralizing antibodies cannot protect reinfection with the same but mutated virus strain ${ }^{26}$.

Finally, as every aspects of the immunobiology of SARS-CoV-2 has yet been under investigations and behavior of the virus in vivo cannot be predicted altogether, we have to wait few more time to conclude anything, including laboratory confirmation, of the virus.

\section{References :}

1. World Health Organization (WHO). Novel coronavirus (2019$\mathrm{nCoV}$ ) Situation report-22 on 11 February, 2020. Published online at: https://www.who.int/docs/default-source/coronaviruse/situation -reports/20200211-sitrep-22-ncov.pdf?sfvrsn=fb6d49b1 2 . Accessed on 01.07.2020.

2. World Health Organization (WHO). Corona virus disease (COVID-19) Situation report-162 on 30 June 2020. Published online at: https://www.who.int/docs/default-source/coronaviruse/ 20200630-covid-19-sitrep-162.pdf?sfvrsn=e00a5466_2. Accessed on 01.07.2020.

3. World Health Organization (WHO). Novel corona virus (2019$\mathrm{nCoV}$ ) Situation report 1 on 21 January 2020. Published online at: https://www.who.int/docs/default-source/coronaviruse/situationreports/20200121-sitrep-1-2019-ncov.pdf. Accessed on 01.07.2020.

4. Zhu N, Zhang D, Wang W, Li X, Yang B, Song J, et al. A novel coronavirus from patients of pneumonia in China, 2019. N Engl J Med. 2020; 382(8):727-33

5. World Health Organization (WHO). Novel corona virus (2019$\mathrm{nCoV}$ ) situation report-11 on 31 January, 2020. Published online at:https://www.who.int/docs/default-source/coronaviruse/ situation -reports/20200131-sitrep-11-ncov.pdf?sfvrsn=de7c0f7_4. Accessed on 01.06.2020.

6. World Health Organization (WHO). Addendum to fact sheet 15 on national implementation measures for the International Health Regulations (IHR) 2005- COVID-19 as a Public Health Emergency of International Concern (PHEIC) under the IHR. WHO Fact Sheet 15A, May 2020. Published online at: https://extranet.who.int/sph/sites/default/files/documentlibrary/document/FS15A_IHR_COVID19_EN_MAY_2020.pdf. Accessed on 01.06.2020

7. Coronaviridae Study Group of the International Committee on Taxonomy of Viruses. The species Severe Acute Respiratory Syndrome- related corona virus: classifying 2019-nCoV and naming it SARS-CoV-2. Nature Microbiol. 2020;5(March2020): $536-44$.

8. World Health Organization (WHO). Coronavirus disease 2019 (COVID 19) Situation report-51 on 11 March 2020. Published online at: https://www.who.int/docs/default-source/coronaviruse/ situation-report $/ 20200311$-sitrep-51-covid-19.pdf?sfvrsn= 1ba62e57_10. Accessed on 01.06.2020.

9. Morens DM, Daszak P, Markel H, Taubenburger JK. Pandemic COVID-19 Joins History's Pandemic Legion.mBio11:e00812-20. Available online at: https://mbio.asm.org/content/ mbio/11/ 3/e00812-20.full.pdf. Accessed on 06.06.2020.

10. Lam TT, Jla N, Zhang Y, Shum MH, Jlang J, Zhu H, et al. Identifying SARS-CoV-2-related coronaviruses in Malayan pangolins. Nature. 2020; 583:282-85.

11. Ji W, Wang W, Zhao X, Zai J, Li X. Cross-species transmission of the newly identified coronavirus 2019-nCoV. J Med Virol. 2020;90:433-40.

12. Lau SKP, Luk HKH, Wong ACP, Li KSM, Zhu L, He Z, et al. Possible bat origin of Severe Acute Respiratory Syndrome Coronavirus 2. Emerg Infect Dis. 2020;26(7):1542-47.

13. Van Doremalen N, Bushmaker T, Morris DS, Holbrook MG, Gamble A, Williamson BN, et al. Aerosol and surface stability of SARS-CoV-2 as compared with SARS-CoV-1 [Letter to the Editor]. N Engl J Med. 2020; 382(16):1564-67.

14. World Health Organization (WHO). Laboratory testing for coronavirus disease 2019 (COVID-19) in suspected human cases. Interim guidance, 2 March, 2020. Available online at:https://apps.who.int/iris/bitstream/handle/10665/331329/WHOCOVID-19-laboratory-2020.4-eng.pdf?sequence $=1$ \&isAllowed=y. Accessed on 15.05.2020. 
15. World Health Organization (WHO). Surveillance case definitions for human infection with novel corona virus (nCoV) Interim Guidance, 20 March, 2020. WHO reference number: WHO/2019nCoV/SurveillanceGuidance/2020.6. Published online at: https://www.who.int/publications/i/item/global-surveillance-forhuman-infection-with-novel-coronavirus-(2019-ncov), Accessed on: 12.06 .2020

16. World Health Organization (WHO). Laboratory testing for corona virus disease 2019 (COVID-19) in suspected human casesInterim Guidance, 19 March 2020. Reference number: WHO/COVID-19/laboratory/2020.5. Published online at: https://apps.who.int/iris/bitstream/handle/10665/331501/WHOCOVID-19-laboratory-2020.5-eng.pdf, Accessed on: 12.06.2020.

17. Communicable Disease Control (CDC), Directorate General of Health Services (DGHS), Ministry of Health \& Family Welfare, Bangladesh. National guidelines on clinical management of corona virus disease 2019 (COVID-19). Version 4,0- 30 March 2020.

18. Minich J, Ali F, Marotz C, Belda-Ferre P, Chiang L, Shaffer JP, et al. Feasibility of SARS-CoV-2 viral detection from consumer grade cotton swabs.[Preprint copy] medRxiv preprint.

19. Freire-Paspuel B, Vega-Marino P, Velez A, Castillo P, GomezSantozEE, Cruz M, et al. Cotton tipped plastic swabs for SARSCoV-2 RT-qPCR diagnosis to prevent supply shortages. Front Cell Infect Microbiol. 2020;10:356.

20. Pan Y, Zhang D, Yang P, Poon LLM, Wang Q. Viral load of SARS-CoV-2 in clinical specimens. [Letter to the Editor]. Lancet. $2020 ; 20: 411-12$.

21. Zhang Y, Chen C, Zhu S, Shu C, Wang D, Song J, et al. Isolation of 2019-nCoV from a stool specimen of a laboratory-confirmed case of the coronavirus disease 2019 (COVID-19). CCDC Weekly.2020; 2(8):123-24.

22. Kim JM, Kim HM, Lee EJ, Jo HJ, Yoon Y, Lee NJ, et al. Detection and isolation of SARS-CoV-2 in serum, urine and stool specimens of COVID-19 patients from republic of Korea.Osong Public Health Res Perspct.2020; 11(3):112-17.

23. World Health Organization (WHO). Laboratory biosafety related to coronavirus 2019 (COVID-19). Interim guidance, 13 May, 2020. Available online at: https://www.who.int/publications/i/item/ laboratory-biosafety-guidance-related-to-coronavirus-disease(covid-19). Accessed on 15.06.2020.

24. Sansure Biotech. Novel Coronavirus (2019-n-CoV) Nucleic Acid Diagnostic Kit (PCR-Fluorescence Probing). Version:V00, Revision date: 05.04.2020. Hunan, China: Sansure Biotech Inc. 2020. Available online at: https://www.fda.gov/media/137651/ download, Accessed on 25.05.2020.

25. Kucirka LM, Lauer SA, Laeyendecker O, Boon D, Lessler J. Variation in false-negative rate of reverse transcriptase polymerase chain reaction-based SARS-CoV-2 tests by time since exposure. Ann Intern Med. 2020 Aug 18; 173(4):262-267.

26. Islam MR, Hoque MN, Rahman MS, Alam ASMRU, Akther M, Puspo JA, et al. Genome-wide analysis of SARS-CoV-2 virus strains circulating worldwide implicates heterogeneity. Scien Reports. 2020:10:14004. 